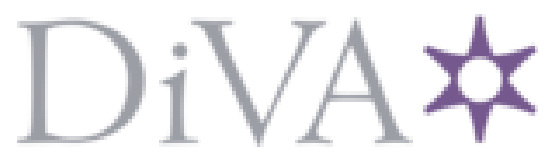

http://www.diva-portal.org

\title{
Postprint
}

This is the accepted version of a paper published in Edda. Nordisk tidsskrift for litteraturforskning. This paper has been peer-reviewed but does not include the final publisher proof-corrections or journal pagination.

Citation for the original published paper (version of record):

Salomonsson, A. (2014)

Flugan och förtrycket: Det koloniala och patriarkala våldets individuella och universella aspekter i Sofi Oksanens Utrensning.

Edda. Nordisk tidsskrift for litteraturforskning, 101(1): 52-66

Access to the published version may require subscription.

N.B. When citing this work, cite the original published paper.

Permanent link to this version:

http://urn.kb.se/resolve?urn=urn:nbn:se:Inu:diva-3447 1 


\section{Flugan och förtrycket. Det koloniala och patriarkala våldets individuella och universella aspekter i Sofi Oksanens Utrensning}

\section{Individual and universal aspects of colonial and sexual violence in Sofi Oksanen's Purge}

Den finsk-estniska författaren Sofi Oksanen (född 1977) har rönt stora internationella framgångar med sin tredje roman Utrensning (2008) ${ }^{1}$ som behandlar frågor om kvinnors utsatthet för våld, i både krigs- och fredstid. Den utgör den andra delen i en romanserie om Estlands 1900-talshistoria, vars övriga titlar är Stalins kossor (2003) och När duvorna försvann (2012). I Utrensning skriver Oksanen på finska, om estniska öden, och hon befinner sig således i en position mittemellan två kulturer, på gränsen mellan det som har kallats Västrespektive Östeuropa. Utifrån den speciella synvinkeln skildrar hon två kvinnors erfarenheter med ett detaljrikt språk och ett berättargrepp som placerar läsaren i brytpunkten mellan det förflutna och nuet.

Romanens Aliide lever ensam på sin familjegård på den estländska landsbygden sedan den ryske maken Martin dött, och dottern Talvi lämnat Estland för ett liv i Finland. Det är i den gamla Aliides kök berättelsen tar sin början, då hon en dag på gårdsplanen ser en medvetslös ung kvinna, som senare visar sig vara hennes systers dotterdotter Zara. Romanen är ickekronologiskt berättad och spänner från 1930-talet till 1992, året efter Estlands självständighet. Berättarperspektiven växlar mellan de båda kvinnornas, och texten innehåller dessutom inslag av diktcitat, fiktiva dagboksanteckningar och KGB-rapporter. Den bildar således ett komplext pussel beträffande både innehåll och form, vilket har tilltalat flera uttolkare. Bland annat har dessa framhållit Oksanens synliggörande av kvinnors historia samt hennes suggererande berättarteknik där det kroppsliga minnet ges stor betydelse för förståelsen av sig själv och historien. ${ }^{2}$

I Utrensning tar förtrycket olika former. Den unga Zara från Vladivostok utsätts för grova övergrepp i en tid då Sovjetregimen just har fallit och brottsligheten florerar i det 
maktvakuum som råder. Med löfte om en bättre framtid i kapitalismens väst, lockas hon att lämna sina fattiga hemförhållanden i hemstaden, men faller istället offer för trafficking och förvandlas till en hårt kontrollerad handelsvara. Även Aliide har utsatts för grovt våld. Att hon som ung på 1940-talet blivit våldtagen av sovjetmilitärer i kommunalhusets källare är en händelse som har färgat hennes liv. I övergreppet mot henne samverkar förtryck av flera slag; hon utsätts dels på grund av sin könstillhörighet, dels på grund av sin etnicitet. I båda fall är det sexuella våldet ett maktuttryck för patriarkalt och kolonialt förtryck.

Syftet med denna artikel är att undersöka närmare hur Oksanen gestaltar det dubbla förtryckets psykologiska konsekvenser, framför allt i explicita och implicita beskrivningar, men även i formella inslag såsom framställning av minnen och tid. Med hjälp av ett kombinerat postkolonialt och feministiskt perspektiv vill jag studera Aliides och Zaras inre ambivalens och hur de hittar strategier för att överleva i ett totalitärt maktsystem, hur de bearbetar det våld de har utsatts för och hur de på olika sätt utmanar förtryckarmakten. I studiet av det dubbla förtrycket är det intressant att som inledande utgångspunkt beakta romanens estniska kontext och skildringen av de kulturellt underordnades relation till två maktcentra: dels den sovjetiska ockupationsmakten, dels den västerländska kapitalistiska maktordningen vars hegemoniska ställning efter självständigheten 1991 varit obestridlig. ${ }^{3}$ Eftersom komplexa och samverkande maktstrukturer beskrivs i romanen, tillämpas i analysen de postkoloniala och feministiska perspektiven på ett integrerat sätt. Detta dubbla förtryck uppträder olika beroende på karaktärernas specifika levnadsförhållanden och därför görs jämförelser mellan deras erfarenheter för att peka på viktiga likheter och skillnader dem emellan.

Studiet av förtryckets tematik i romanen pendlar således mellan en individuell och en universell nivå. En fruktbar metodologisk utgångspunkt finner jag hos Dipesh Chakrabarty som, i sin studie av Indien, placerar sig i spannet mellan det han kallar den analytiska och den hermeneutiska traditionen. Den analytiska traditionen, representerad av Marx, tenderar att översätta lokala företeelser och den enskilda människan till universella abstraktioner, medan den hermeneutiska, å sin sida, representerad av Heidegger, fokuserar de konkreta levnadsförhållandena: "[This tradition] produces a loving grasp of detail in search of an understanding of the diversity of human life-worlds. [...] [It] finds thought intimately tied to places and to particular forms of life” (Chakrabarty 2008: 18). Det är med andra ord i själva spänningsfältet mellan de individuella erfarenheterna och den universella företeelsen, som ny kunskap kan skapas - men utan att den specifika kontextens betydelse, i det här fallet betydelsen av Aliides och Zaras enskilda livsöden, därmed förminskas. 
Det koloniala våldets konsekvenser för människans självbild har beskrivits av Frantz Fanon i Svart hud, vita masker (1952) och Jordens fördömda (1961). Fanon behandlar relationen mellan Frankrike och Algeriet men framhåller att det koloniala förtrycket rymmer en mängd universella aspekter, i det att "[a]lla former av exploatering är identiska, ty de tillämpas alla på samma 'objekt’: människan” (Fanon 2011: 91). Enligt Fanons psykoanalytiska förklaringsmodell leder det systematiska förtrycket till att människan reducerar sig själv och anammar kolonisatörens syn på henne som objekt. Genom att tidigt lära sig identifiera de vita kolonisatörernas modernitet som ideal blir följden att den koloniserade betraktar sig själv och den egna kulturen som essentiellt underordnad, en reaktion Fanon kallar ”underdånighetens psykos” (Fanon 2007: 55). De psykologiska reaktioner som människor uppvisar i det ockuperade Estland kan alltså jämföras med koloniserades reaktioner i andra länder. Paralleller har emellertid sällan dragits mellan de postsovjetiska staterna och det Fanon kallar Tredje Världen, ${ }^{4}$ trots att Sovjetmaktens imperialistiska ambitioner har varit i samma storleksordning som västländernas (Moore 2006: 11). En orsak är enligt Violeta Kelertas att maktrelationen mellan Sovjetunionen och Baltikum bryter mot den konventionella centrum-periferi-relationen enligt vilken kolonisatören per definition är västeuropé. Historiskt har balterna snarare identifierat sig med kolonisatörerna i Europas metropoler än med dem i Europas kolonier, och med motsvarande dualistiska synsätt har de psykologiskt betraktat sig själva som mer civiliserade än de ”orientaliska” ryssarna från öst (Kelertas 2006b: 252). ${ }^{5}$ Estland hade styrts av Ryssland under två sekler, när landet förklarades självständigt 1918. Den nationella frihetsperioden tog dock slut 1940, då ryssarna åter ockuperade landet. Året därefter och tre år framåt, 1941 - 1944, var Estland under tyskt styre, för att i krigets slutskede åter ockuperas av Sovjetmakten, en av andra världskrigets segrare (Sillaste 1995). Efter självständigheten 1991 har den estländska kompassen åter vänts mot väst. ${ }^{6}$

Landets historia belyser dess komplexa relation till maktcentra i både öst och väst. I likhet med andra östeuropeiska länder intar Estland en sorts mellanposition, såväl geografiskt som statusmässigt, vilket speglar att en gradering mellan europeiska länder förekommer i synen på modernitet. Den tydligaste skiljelinjen går mellan Väst- och Östeuropa där det förra betraktar det senare som delvis innanför, delvis utanför den europeiska vi-moderniteten. Tillståndet att vara ett "ofullständigt” europeiskt subjekt har behandlats av bland andra Maria Todorova, i en studie om Balkans specifika kontext. Hennes beskrivning av balkansubjektets ambivalens har stora likheter med det baltiska subjektets. Att vara, som Todorova kallar det, ”an incomplete self” markerar en statusskillnad i relation till båda riktningar på den av väst 
upprättade modernitetsskalan: Hon betraktas å ena sidan som "incomplete” i relation till väst, å andra sidan som ett mer utvecklat "self” än ”the incomplete other”, öster om Europas gränser (Todorova 2009: 18). Denna de östeuropeiska ländernas underordning har, efter Sovjetmaktens fall, i olika grad åter befästs. David C. Moore skriver: “[Eastern Europe have] returned to their former status as the West's Third World, its nearest quasi-oriental space” (Moore 2006: 27). Somliga har kritiserat analogin mellan det koloniserade i Tredje Världen och ”Tredje Världen i Väst” på grund av de skilda kontexterna. Ett argument som rests är att många östeuropeiska länder har en lång nationell historia, under vilken man politiskt och kulturellt utvecklades parallellt med väst. Ett annat argument är att Sovjet aldrig erövrat länder bortom haven, utan i direkt anslutning till det egna territoriet, och därför inte kvalificerar som kolonialmakt. ${ }^{7}$ Trots de kontextuella skillnaderna anser bl.a. Kelertas och Moore, och jag med dem, att postkoloniala teorier likväl är fruktbara att pröva på såväl Baltikum som Östeuropa i stort, om man gör det med försiktighet. Kelertas skriver: ”[It is not] whether postcolonialism fits the Baltic case, but how it applies in the wider context of postSoviet nations” (Kelertas 2006 a: 2).

Beträffande förtrycket av icke västerländska kvinnor kännetecknas det av att koloniala och patriarkala maktstrukturer är verksamma samtidigt. I Feminism Without Borders (2003) beskriver Chandra Talpade Mohanty hur sådant strukturellt förtryck utgör ett naturaliserat inslag i mångas tankevärld:

The interwoven processes of sexism, racism, misogyny, heterosexism are an integral part of our social fabric, wherever in the world we happen to be. We need to be aware that these ideologies, in conjunction with the regressive politics of ethnic nationalism and capitalist consumerism, are differentially constitutive of all our lives [...]. (Mohanty 2003: 3)

Dessa flerbottnade maktstrukturer återfinns med andra ord världen över. I Oksanens roman representeras detta förtryck av dels Sovjetmakten, dels de ryska hallickarna som orienterat sin verksamhet mot den nya kapitalismen i väst. Men det faktum att kvinnor delar liknande erfarenheter av våld, såsom skildrat i Utrensning, innebär dock inte att dessa kvinnor förutsättningslöst sympatiserar med varandra. Mohanty understryker att solidaritet mellan människor inte grundar sig på förenklade kategoriseringar såsom kön, etnicitet och klass, utan snarare på hur vi tänker kring sådana begrepp (Mohanty 2003: 6). Begreppet "globalt systerskap” är olyckligt, hävdar hon, då det rymmer ett glapp mellan den teoretiska konstruktionen och den diskursiva meningsproduktionen av begreppet (Mohanty 2003: 110). Eftersom det tenderar att tolkas essentiellt, med den vita västerländska medelklasskvinnan 
som norm, osynliggörs de historiska och de samtida implikationerna. Om exempelvis kolonialt och patriarkalt förtryck tolkas som ahistoriska begrepp, fråntas den förtryckta möjligheten att själv agera som ett historiskt och politiskt subjekt. I linje med Chakrabarty, framhåller Mohanty den diskursiva dimensionens betydelse och riktar intresse mot den historiska materialismen; både den mikropolitiska kontexten, som rör subjektivitet och identitet, och den makropolitiska, som inkluderar rådande globala, ekonomiska och politiska processer (Mohanty 2003: 112f). I stället för "globalt systerskap” förordar Mohanty begreppet ”solidaritet”, och vill definiera det genom att teoretisera kring de verkliga skillnader, och problem, som gränser mellan människor medför. Om vi vågar se tystnader och exkluderingar kan vi varsebli gränsernas spänningar av samtidig pluralitet och trångsynthet, samt den emancipatoriska potentialen i att, i vårt dagliga liv, kunna överskrida dessa gränser. Mohanty talar om ”cross-cultural och cross-national borders" (Mohanty 2003: 2) men i Utrensning utgörs gränserna även av generationstillhörighet. Förståelsen av samhörighet är alltså inte en naturgiven gemenskap, utan en identifikation grundad på en ”föreställd gemenskap”, ett uttryck lånat av Benedict Anderson (Mohanty 2003: 46f). Man måste således självreflexivt tillägna sig den, i den egna historiska kontexten. Denna definition av kvinnors tillägnade solidaritet gör Mohantys idé överförbar på studier överlag som berör kvinnor som, var de än bor i världen, lever, och har levt, under skilda former av kolonialt och patriarkalt förtryck. Det är en definition som dessutom harmonierar med Kelertas och Moores generösa syn på den postkoloniala teorins möjligheter, i kraftfältet mellan det individuella och det universella. Och fastän detta dubbla synfält är begränsat såtillvida att vi aldrig helt och fullt kan förstå den andra, då det alltid existerar ett avstånd som ytterst utgörs av individuella faktorer, kan vi åtminstone verka för att distansen ska minskas. Det kan bl.a. göras genom att vi medvetet studerar enskilda exempel, såsom skildringen av två estländska kvinnors olika erfarenheter, genomlysta i det universellas spänningsfält, i syfte att synliggöra tendenser som ytterligare kan beskriva människans förhållanden i världen.

\section{Överlevnadsstrategier}

Utrensning utspelar sig huvudsakligen på två skiftande tidsplan, dels under perioden mellan 1936 och 1951, dels under tiden strax efter landets självständighet, 1991 och 1992. Platsen är däremot i stort sett densamma i hela romanen: den estniska landsbygden i och omkring Aliides barndomshem. Fastän huvudkaraktärerna Aliide och Zara har vitt skilda bakgrunder delar de erfarenheter av systematiskt förtryck, vilka har begränsat deras handlingsutrymme att 
självständigt forma sina liv. Aliide och Zara har kommit att se sig själva med förtryckarnas manliga blick såsom icke fullvärdiga människor. Karaktärsbeskrivningarna kan i ljuset av Fanons idéer belysa hur människans självuppfattning påverkas i grunden av våldsövergrepp. Den förtryckta människan påverkas psykologiskt av det systematiska våld hon utsätts för genom att översättas till ett underordnat objekt fråntagen mänskliga attribut. Enligt Fanon betraktar hon sig själv utifrån, med makthavarens blick, som något smutsigt och värdelöst och alienerar sig således från sitt eget jag för att överhuvudtaget kunna överleva i ett totalitärt maktsystem (Fanon 2011: 111ff). Mohanty framhåller att Fanons maskulint präglade teorier om kolonialt våld kan överföras till en feministisk diskurs (Mohanty 2003: 7f) och i Utrensning är de fanonska parallellerna många. Det är tydligt att Zara betraktar sig som objekt när hon iklär sig rollen som Natasja. Det är Natasja, inte Zara, som under ett års tid säljs som sexslav av hallicken Pasja, och som han och kunderna kan behandla utan någon som helst människovärdig respekt. För Zara innebär rollbytet en livsnödvändig distansering från allt det vidriga hon är tvungen att utstå och hon fjärmar tankarna från den egna kroppen för att inte helt gå under.

Förtrycket mot Zara konstitueras inte endast av patriarkala utan även av koloniala strukturer. Att hennes kropp exploateras och säljs över de öppna nationsgränserna västerut är ett exempel på att de ryska hallickarna utnyttjar marknadens efterfrågan på den ryska och östeuropeiska kvinnans sexuella tjänster. Föreställningen om henne kan jämföras med de spridda stereotypa bilderna av den östeuropeiska kvinnan som ett sexualiserat och alltid tillgängligt objekt. ${ }^{8}$ Betraktandet av de andras kroppar som handelsvaror möjliga att utnyttja visar sig även i synen på östeuropeiska kvinnor - och män - som billig arbetskraft på arbetsmarknaden i väst. ${ }^{9}$ I Utrensning betraktas således den unga ryskan Zara i både kolonialt och patriarkalt avseende som den andra. Hennes överlevnadsstrategi i form av självdistans är dock inte alltid lätt att upprätthålla. Senare, när Zara har lyckats fly och befinner sig hos Aliide, tränger ibland självdestruktiva tankar fram och fyller henne med tvivel. ”Någonstans i bakhuvudet flimrade ett skratt, det lät som Pasja, och det påminde Zara om att en så här dum flicka inte klarar av någonting på egen hand” (25). När Aliide senare ställer närgångna frågor om vem hon egentligen är, delges vi åter Zaras inre kamp över sin självbild, när hon intalar sig att Pasja nog hade rätt ändå, ”att hon helt enkelt inte var en sådan person som kunde uppföra sig ordentligt, annat än under hot om stryk. Kanske hade hon faktiskt något i sig som var ont och odugligt, något som var fel vid födseln” (64f). Zaras återfall i självdestruktiva tankar förstärks av Oksanens val av berättarteknik. Med den inre monologen till hjälp, åskådliggörs att betraktandet av Zara som objekt inte endast kommer utifrån, utan även inifrån henne själv. Det 
har naturaliserats i hennes eget medvetande. Vid sådana tillfällen tänker hon som om hon vore Natasja. Då ser hon sig själv med Pasjas ögon: som en skamlig kvinna, ett ovärdigt objekt.

I porträttet av Aliide gestaltas den destruktiva självbilden som ännu djupare rotad, fastnaglad i hennes medvetande sedan ett halvt sekel tillbaka. Emellertid råder en stor skillnad i hur Oksanen gestaltar karaktärernas medvetenhet om denna inre kamp om självdefinitionen. Berättartekniskt delges visserligen även Aliides erfarenheter ofta i form av inre monolog, men i kontrast till de mer explicita tankarna hos Zara, manifesteras Aliides självbild endast implicit, som ett tecken på att tankarna ligger förträngda, utom räckhåll för hennes medvetna jag. En sådan implicit beskrivning av självbilden finner vi i bokens inledande scen. Den spelar i sammanhanget en central roll, eftersom den vittnar om Aliides ickeverbala, men djupa, självförakt. Medan Zara som skydd har iklätt sig rollen som Natasja, har Aliide antagit någonting ännu lägre och smutsigare - nämligen identiteten av en fluga:

Aliide Truu stirrade på flugan och flugan stirrade tillbaka. Flugans ögon stod ut och Aliide kände avsmak. En spyfluga. [...] Trots att Aliide redan under mer än en timme försökt ta livet av flugan hade den kommit undan och överträffat henne vid varje slag, och nu flög den alldeles intill taket och surrade grovt. En obehaglig spyfluga som växt upp i ett smutsigt dike. (10f)

Det är sin egen blick hon möter i den låga varelsen framför sig. Ända sedan Aliide år 1947 anklagades för samarbete med motståndsrörelsen och utsattes för en gruppvåldtäkt i Kommunalhusets källare har hon upprätthållit sin självalienerade jagbild. I likhet med Zara har hon därigenom kunnat lösgöra sig från sin egen kropp som en ren överlevnadsstrategi. Under förhöret känner hon källarlukten genom påsen som de trätt över hennes huvud.

Dörren öppnades. Stövlar. Aliides skjorta slets upp, knapparna smattrade mot stengolvet, mot väggarna [...]. Hon var en fluga och hon gick tvärs över en kvinnas bara bröst [...]. Kvinnan mitt i rummet med en påse över huvudet var en främling och Aliide var borta. [...] [H]on var en fluga som flög undan, upp i taket, bort från lampans sken, genomskinliga vingar, hundra ögon, men kvinnan på golvet rosslade och ryckte. Hon hade en påse över huvudet och påsen luktade spyor och hade inget hål för flugan [...]. Dörren smällde, stövlarna smällde, ovanför stövlarna smackade man, knäppte med tungan, brödsmulor föll som block ner i golvet. Smackandet upphörde.

- Hon stinker. Ta bort henne.

Hon vaknade upp i ett dike. (141f)

Den förnedring hon upplever förstärks av att hon vaknar upp i det smutsiga diket, en symbolisk bild som sammanlänkar de två scenerna ovan. Flugans närvaro är ett återkommande inslag i romanen, liksom på andra håll de hotande spindelnäten och flugsmällans klatschande. Konflikten mellan flugan och spindeln blir en metafor för Aliides 
inre identitetskonflikt där hon slits mellan sitt självdestruktiva jag och den del av jaget som bejakar den egna estniska bakgrunden och det systern Ingel representerar. Spåren av spindelns närvaro väcker förträngda känslor hos Aliide, som när hon året dessförinnan, 1991, rensar undan viktiga dokument på vinden och ”[...] träffades av spindelväv som svävade emot henne, och en underlig smak av vemod” (91). Hela sitt vuxna liv har Aliide dock varit en flugans fånge och levt i ett slutet maktsystem, med kunskap endast om det ramverket, och utan att se något alternativ förblir den destruktiva självbilden för henne en strategi för att lyckas med det som förväntas av henne - som kvinna och hustru och som kommunistisk medborgare och agent. Att det kodnamn Aliide bär som sovjetisk agent senare visar sig vara Kärbes, det estniska ordet för fluga (352, 363), förstärker denna självbild.

Oksanens skildring av kvinnorna är således mångbottnad. Alltsedan den unga Aliide förrådde systern på grund av en obesvarad kärlek till svågern och motståndsmannen Hans Pekk, har Aliide levt i en livslögn som hon inte förmått konfrontera. Under några år efter att systern och systerdottern deporterats höll hon av själviska skäl Hans gömd i lönnkällaren undan kommunisterna, och genom sitt svek fråntog hon därmed systern och hennes familj möjligheten till ett egenvalt liv. Hennes smutsiga självbild bottnar därmed inte endast i att hon har berövats en sexuell och kulturell självständighet, utan också i att hon själv har innehaft rollen som förövare. Även Zara är en förövare. Först efter att i Tallinn ha dödat en kund, tillika Pasjas chef, lyckas hon fly och fullfölja planen att söka upp sin mormors syster på den estländska landsbygden. Följaktligen är varken Zaras eller Aliides samveten rena från skuld.

\section{Symptom}

Som en konkret följd av det sexuella våldet upplever Aliide och Zara sig vara kroniskt smutsiga. Deras upplevelse kan ses som ett symptom på den skuld de lägger på sig själva och sina egna kroppar. När Aliide som nygift får tjänst på ett kolchoskontor och där känner igen en av männen från kommunalhusets källare, påminns hon om sin orena kropp och tvättar sig med hett vatten när hon kommit hem, och flera dagar därefter:

När hon fått iväg Martin skalade hon av sitt ansträngda leende, tvättade händerna, doppade ansiktet i tvättfatet och stapplade till lagården. [...] Och hon orkade inte bege sig med mjölken till mejeriet eller till sitt arbete på kolchoskontoret.[...] Sedan tappade hon upp ett bad, tvättade håret, värmde vatten trots att det var så hett att man inte hade kunnat elda i spisen. Porerna flämtade, andningen pep. Mannen skulle ändå minnas henne förr eller senare. Hon kunde inte arbeta kvar på kontoret. [...] Flugorna surrade och hon slog efter dem med flugsmällan, svetten rann i bäckar, Aliide slog flugor i lampan, på stolen, på öltunnan, ullsaxen, tvättbaljan och på sågen som hängde på väggen. 
Självföraktet, gestaltat av de smutsiga flugornas närvaro, gör att hennes behov att tvätta sig har övergått till en fix idé hon inte längre reflekterar över. Fyrtio år senare betraktar Zara hur den gamla Aliide ”[...] slog sig ner, reste sig, tvättade händerna, satte sig, pysslade med något, tvättade på nytt händerna i samma vatten, torkade dem, undersökte burkarna och sitt recepthäfte, skalade, tvättade händerna, det oupphörliga sysslandet gav inget utrymme för några tolkningar” (45). Å ena sidan håller småbestyren smärtsamma tankar på armlängds avstånd, å andra sidan avslöjar det idoga tvättandet att Aliides smutsiga självbild har naturaliserats av de värderingar som makten representerar. Hennes inre ambivalens märks emellertid när hon betraktar Zaras nybadade och misshandlade kropp:

Över bröstet löpte ett ärr som försvann in under handduken. Aliide kände avsmak. Flickan i dörröppningen såg yngre ut när hon var rentvättad, hennes hy påminde om köttet i ett nyskuret kaneläpple. Det droppade vatten från hennes hår. Doften från den nytvättade flickan spred sig i kammaren [...]. Hon undvek att se på flickan, studerade rören längs väggen, de fungerade fortfarande, hon knackade med sin käpp på ett av de gröna rören och tog bort lite spindelväv.

- Det finns grobladsextrakt där på bordet. Det hjälper huden att läka snabbare. (42)

Aliide växlar mellan avsmak och sympati. Avsmaken visar sig i att Aliide betraktar flickan, liksom sig själv, som skamfylld och smutsig. Det blir tydligt när hon reflexmässigt undanröjer de för flugan så hotande spindelväven. Genom att hindra spindelns framfart kan hon rädda flugan, vilket metaforiskt understryker hur hon upprätthåller den självdestruktiva självbilden och för stunden undviker att konfrontera sina smärtsamma minnen. Sympatin å andra sidan syns i det att Aliide trots allt erbjuder Zara grobladsextraktet hon tillverkat på traditionellt estländskt vis och att hon liknar Zaras hy vid det vita fruktköttet i ett kaneläpple, kanske från den egna trädgården. ${ }^{10}$ Även morgonen därpå, när Zara vaknar till Aliides skramlande i köket och de estnisk-kulinariska dofterna, gestaltas ambivalensen i form av kampen mellan flugan och spindeln. Just denna morgon har spindeln övertaget:

[Zara] öppnade ögonen och såg hörnet av en främmande ryamatta på väggen. Hon var i Aliide Truus hus. Det var bubblor i tapeten, sömmarna var inte raka. Mellan ryan och tapeten svävade ett skört spindelnät som ett dis, där hängde en död fluga. Zara flyttade på ryan med fingret, en spindel kravlade sig under den. Hon var nära att trycka till spindeln med ryan, men kom sedan ihåg att om man dödar en spindel betyder det att ens egen mamma dör. Hon strök med handen över ryan. Huvudet var lätt, huden kändes vårlik mot nattlinnet [...], hon kände fortfarande doften av tvål i näsan. (54) 
Zara dödar inte spindeln, ty det skulle enligt talesättet betyda den egna moderns undergång. Oksanen låter sålunda spindeln representera det estniska kultur- och modersarvet, vilken tack vare Zaras kunskap, ges fortsatt möjlighet att utmana Aliides förhärskande flugjag. Dessutom ger tvålen från gårkvällens renande bad spindeln ytterligare fördel i den kampen. Tvättandets symboliska betydelse i romanen understryks av att tvål vid flera tillfällen produceras i husets kök enligt traditionellt recept. Den hemmagjorda tvålens verkan ställs i slutet av romanen mot den inköpta tvålen av det brittiska märket Imperial Leather. ${ }^{11}$ Det är en av de västerländska produkter dottern Talvi köpt med sig från Finland, och det är den tvålen Pasja fingrar på när han på jakt efter Zara inspekterar i Aliides kök (278). Här sammansmälter de sovjetiska, kapitalistiska och patriarkala krafterna till ett enda maktcentrum i representationen av den ryska hallicken Pasja. Doftande Imperial Leather-tvål och Marlboro, visar Pasja fotografier på Zara: ’[De] var framkallade på västerländskt papper, de hade en västerländsk glans. Zaras klara läppstift lyste mot den matta vaxduken. De stickiga ögonfransarna bredde ut sig som kronblad mot den ljusblå pärlemorglansen som kladdigt omgav ögonen” (281). Det fragmenterade, objektifierande sättet på vilket flickan på fotot beskrivs laddar texten med mening om vilket förtryck flickan lever under. Det är den prostituerade Natasja som vi ser på det västerländska fotot, vilket färgstarkt och glansigt kontrasterar den estniska, matta vaxduken. Fotografiet representerar dock en falsk ytlighet. Den äkta Zara sitter dold i Aliides mörka lönnkällare.

I sammanhanget förtjänar Oksanens val av titel att kommenteras närmare. Den svenska titeln Utrensning saknar nämligen en viktig nyans i jämförelse med originalets finska titel Puhdistus. Den senare inrymmer inte endast betydelsen "rensning”, utan även betydelsen ”tvättning” (Talgre 2012). Eftersom "rensning” i kombination med attributet "etnisk” är ett etablerat begrepp, leder titeln tankarna till gallring av människor i form av mord och deportationer, medan ”tvättning” å sin sida speglar den enskilda kvinnans handling att med tvål och vatten eliminera smuts från sin kropp. I sin romantitel kan Oksanen därmed metaforiskt rymma flera universella aspekter av förtryck: dels det koloniala förtrycket av ett helt folk, dels det sexuella förtrycket av kvinnors kroppar. Mot bakgrund av titelns dubbeltydighet kan berättelsen om Aliides enskilda öde även tolkas som en allegori om nationen Estlands femtio år under kolonialt förtryck. Men den skiljer sig från många andra fall där nationen beskrivits med allegoriska paralleller till feminitet. Vanligtvis när kvinnan står som symbol för nationen riskerar hon att reduceras till en abstraktion istället för en nationens fullvärdiga medborgare. Kvinnan som nationssymbol visar, enligt Avtar Brah, att föreställningen om kvinnans roll för bildandet och reproducerandet av nationen är central 
(Brah 2001: 183). I stället för att ses som självständiga subjekt, ses kvinnor som ”förkroppsligande den manliga äran” och utgör ofta den plats där denna ära skall försvaras (Brah 2001: 183). Till skillnad från en sådan könsstereotypisk nationssymbolik, är kvinnorna i Oksanens tappning medräknade som människor av kött och blod. I hennes berättelse om Estlands självständighetskamp, Puhdistus, riktas det symboliska ljuset på samma gång, och med samma styrka, såväl mot det patriarkala förtrycket som mot det koloniala.

\section{Bearbetning}

Medan de uppvisar likartade strategier och symptom som följd av förtrycket, råder dock en markant skillnad mellan Aliides och Zaras sätt att bearbeta sina trauman. Redan i den språkliga gestaltningen av övergreppen, tydliggör Oksanen skillnader dem emellan. Övergreppet på Aliide skildras med utgångspunkt från hennes undermedvetna, och Oksanen återger hur hon förtränger det som händer henne till det doldas minneslager. I direkta ord nämns alltså inte vad som sker, men implicit låter Oksanen oss ändå förstå det ofattbara Aliide utsätts för, och senare också hennes syster Ingel och systerdotter Linda. När Aliide återvänder hem efter den ödesdigra natten koncentrerar hon sig på hur hon ska kunna undvika att systern, eller någon annan, får reda på vad som hänt när hon nu kommer strumplös hem. Hon koncentrerar sig på strumpor hela vägen från diket:

Aliide klappade sig på kinderna, slätade till sitt hår, kände på sitt huvud men det kändes klibbigt, silkesstrumpor, bomullsstrumpor, yllestrumpor, kaprónstrumpor. Vid brunnen tog hon upp en hink vatten, tvättade händerna, gnuggade dem med stenar eftersom ingen borste fanns, bruna strumpor, [...] broderade strumpor, nu måste hon gå in. Klarade hon det? [...] Aliide skuffade in sin kropp på gården, hon såg själv efter den, hur hon gick, hur foten lyftes, hur handen tog i handtaget, hur hennes röst ropade att det är jag. (144)

Medan skildringen av Aliide speglar hennes jagalienation och känslor av skam, är däremot det sätt på vilket Zara förnedras skildrat med en helt annan språkdräkt. Här väjer inte Oksanen för att måla plågsamma bilder i starka färger och formuleringar. Vi läsare kommer inte undan utan delges rakt på sak allt det omänskliga Zara måste utstå. Zara själv kan inte förtränga sina upplevelser utan är tvungen leva med att hennes kropp exploateras dagligen, antingen i verkligheten eller i Pasjas videofilm.

På flera håll i romanen framkommer karaktärernas olika förhållningssätt till det verbala språket. Exempelvis beskrivs hur Aliide redan som barn fostrats till att inte tala om tabun. Bland annat hade hon "fått smäll om hon uttalade ord som Gud, Satan, åskan och döden högt" (177). Även Zaras mor och mormor saknar ord, men istället utbyter de brännande blickar. 
Mellan Zara och mormodern däremot växer ett hemligt språk fram, estniskan, som representerar en alternativ verklighet, beskriven bland annat i mormodern Ingels sång Emasüda, "modershjärtat” (51). När Zara senare berättar för Aliide om sin hemtrakt väller orden fram, och hon beskriver sina minnen från Vladivostok på ett sätt som Aliide å sin sida aldrig skulle ha varit förmögen till (216). Det estniska språket och förmågan att verbalisera sina minnen visar sig bli Zaras livlina, medan den stumhet Aliide lider av är densamma som Zaras mors och mormors - den som närs av förlamande skam och placerar minnena i ett dunkelt undermedvetet.

Som ett led i bearbetningen av kolonialt förtryck är det viktigt att den drabbade återerövrar sina minnen för att därigenom kunna återerövra bilden av sig själv som självständigt subjekt. Enligt Rauna Kuokkanen är det viktigt för kulturellt förtryckta att släppa taget om skammen och våga minnas och bejaka kunskaper knutna till den egna kulturen, vilka har nedvärderats under den dominanta kulturens styre (Kuokkanen m. fl. 2003: 31). I Utrensning ger Oksanen plats åt en estnisk historieskrivning som alternativ bild till den sovjetiska ockupationsmaktens. Detta framkommer även i den narrativa strukturen. Medan Oksanen i de fyra första kapitlen återger Aliides och Zaras berättelser utgörs det femte kapitlet av fiktiva KGB-rapporter från det sena 1940-talets Estland. Exempelvis osynliggörs där gruppvåldtäkten av Aliide vilket rapporteras som ett regelrätt förhör. Den stumma Aliides berättelse kontrasteras sålunda mot de etablerade historieskrivarnas. ${ }^{12}$ Det är särskilt viktigt, menar Kuokkanen, att koloniserade kvinnors erfarenheter ges offentligt utrymme, eftersom kvinnor historiskt inte har tagit den platsen, och inte tillräckligt har lärt sig att uppskatta sina egna berättelser (Kuokkanen m. fl. 2003: 32). De har snarare lärt sig att förminska sina rösters betydelse, på grund av det dubbla förtryckarsystem de levt under. Först när de översätter sig själva tillbaka till sin egen kontext och rekonstruerar sina minnen, kan de återerövra synen på sig själv som självständiga subjekt.

En liknande självständighetsprocess återfinns i skildringen av Zara. Trots Pasjas avhumanisering av henne övergår inte Zara till att fullständigt bli Natasja. Under sin tid som prostituerad intalar hon sig själv ”att även om Zaras ansikte fanns på Pasjas videoband så berättade filmen inte Zaras historia utan Natasjas, den skulle aldrig få bli Zaras egen. Zaras historia fanns någon annanstans. Natasjas historia fanns på bandet” (221). Såsom en motbild till Pasjas bild av henne, håller hon isär de roller namnen symboliserar och bevarar inom sig minnen av sitt självdefinierade jag. Dessa minnen konkretiseras av dels ett pionjärmärke från barndomen dels ett gammalt fotografi på mormodern och Aliide. Pionjärmärket från Vladivostok och fotografiet från Estland symboliserar Zaras förhandlande med sig själv om 
vem hon är, i förhållande till de maktcentra som Pasja representerar, och visar även hennes hybrida kulturella position, som måhända är avgörande för att hon ska kunna vara en förändrande kraft även i Aliides liv. Aliide själv har däremot inga motsvarande motbilder till sin destruktiva självbild, och hon har därför inte heller haft samma förutsättningar att läka. Under sitt vuxna liv har Aliide imiterat makten och till synes helt assimilerats till kommunist. Men assimilationen har sprickor i form av ett tyst och subtilt motstånd. Bakom kommunistfasaden har Aliide med åren förfinat sina kunskaper om estniska recept på såväl tvål som maträtter och läkande växtrecept, vilket skapat grogrund för en växande inre självständighet. Även efter murens fall 1989, fortsätter hon i det tysta att bejaka den lokala kulturen, och markerar därmed ett avstånd från såväl de sovjetiska som de västerländska maktcentra vars hegemoniska krav på assimilering hotar att utrensa den egna kulturens särart.

Aliides strategi kan här liknas vid det Homi K. Bhabha kallar mimicry, en motståndsstrategi som inrymmer en samtidig och dubbel rörelse: den mot förtryckarmakten, genom att försöka likna den, och den från förtryckarmakten, genom det underliggande subtila avståndstagandet (Bhabha 2004). Fastän Aliide inte har haft orden och språket till hjälp i sin läkningsprocess, har hon däremot via ickeverbala och konkreta vardagshandlingar återerövrat gamla estländska kunskaper. Detta blir till ett erkännande av systern Ingel och de kulturella värden som präglade deras gemensamma uppväxt, som fyller en läkande funktion. När Aliide i romanens början erbjuder den nybadade Zara att smörja in kroppen med grobladsextrakt, är orden riktade även till henne själv: ”Det hjälper huden att läka snabbare” (42).

Oksanen beskriver hur de båda kvinnorna har olika tillgång till språk och minnen. Medan Aliide tillhör en generation som förblivit ordlös och självdestruktivt har vänt bördan inåt, verbaliserar den unga Zara det hon har erfarit och vågar agera. Oksanen själv lyfter i en intervju fram generationsaspekten som en förklaring till varför romanens Aliide inte har någon vokabulär för sina upplevelser (Talgre 2012). Den yngre generationen har möjligen fler ord för det upplevda, och kan därmed synliggöra förtrycket för omvärlden så att det lyfts till att vara mer än ett individuellt problem. Ytterligare en fördel med en ny generations tillträde är enligt Karl Mannheim att denna kan ta sig an problem med nya ögon och tillskjuta impulser som den äldre generationen inte förmår inom ramarna för sin förståelsehorisont, vilket på sikt också kan bidra till förändringar på ett mer samhälleligt, generellt plan (Mannheim 1997). Det kan delvis belysa varför de båda kvinnorna förhåller sig olika till det de har varit med om. Emellertid är generationsbegreppet inte oproblematiskt, då inte heller det återger en homogen grupp människor. Det är, i likhet med begrepp som etnicitet, kön och klass, endast en av flera identitetsaspekter som kan utgöra grund för gemenskap och identifikation. 


\section{Solidaritet}

Romanens Aliide känner inte automatiskt samhörighet med Zara på grund av att de delar liknande upplevelser av våld. Tvärtom ser hon till en början på henne som på sig själv; en smutsig kvinna som förtjänar förakt. Det visar sig bland annat när Aliide serverar henne en bit korv med flugägg i:

Hon var redan på väg att kasta korven när hon kom på andra tankar och tog en närmare titt på den. [...] när hon lyfte på pappersomslaget till korven, upptäckte hon en varelse som rörde sig fett vaggande. Aliide kände smak av uppkastning i munnen. Hon grep korven och började skära den i skivor att lägga på flickans smörgås. (44)

Med liknande förakt har hon under åren betraktat andra kvinnor med sänkta blickar, vilka har utsatts för samma förnedring som hon själv. Likt flugan som lägger sina ägg, reproducerar Aliides självförakt förtryckarmaktens syn på dem som smutsiga objekt. Hennes reaktion påminner om Fanons beskrivning av den kolonialt förtryckta som först riktar frustrationen och aggressiviteten mot de egna, trots att frustrationens egentliga orsak grundas i individens frihetslängtan. Men i det maktsystem som råder förutsätts att den underordnade är skyldig, vilket gör att hon alltid är på helspänn. Skammen är hennes och "hänger som en förbannelse” över henne (Fanon 2007: 66).

Varken generationstillhörighet, kulturell bakgrund eller biologiskt systerskap är med andra ord en garanti för lojalitet. Hos Oksanen beskrivs det problematiska med sådana generaliserande identifikationsgrunder inte minst i systrarna Aliides och Ingels relation. Även här gestaltas Aliides känslor implicit, via den självbild som har opererat i hennes undermedvetna sedan ungdomen. Romanens återkommande inslag om kampen mellan flugan och spindeln blir en metaforisk beskrivning av Aliides moraliska identitetskonflikt mellan den hon har varit och den hon har velat vara - systern Ingel. Att flugan har symbolisk betydelse för systerrelationen anas redan när Aliide ser Hans för första gången 1938 stående vid kyrkans stengärdsgård. Emellertid förblir hon osynlig för honom då han endast har ögon för Ingel. När denna styr stegen mot Hans kan ingenting stoppa de två förälskades möte. Ingel drar lillasyster i handen efter sig fastän denna förgäves spjärnar emot:

Gång efter annan grävde skornas klackar ner sig i mullen, men jorden gav vika, rötterna gav vika, granarna gav efter, gräset gled undan, stenarna rullade framför Aliides fötter och en sommarfluga flög rakt in i hennes mun och hon kunde inte hosta ut den, för Ingel ville inte stanna, hon måste gå, och Ingel drog och drog och stigen var tom och ledde raka vägen till stengärdsgården, och Aliide såg mannens blick som var tom och lösgjord från tid och rum, och hon kände Ingels upphetsade steg och fasta grepp om sina fingrar [...]. 
Det är främst genom Aliides inre monolog som scenen återges, och dess formella uppbyggnad är central för tolkningen av den. Oksanens satsbyggnad, som löper snabbt utan punkt, i kombination med beskrivningen av naturens kapitulering, gestaltar såväl Ingels iver och kärlekens stormstyrka som Aliides djupa förtvivlan över att hädanefter vara ratad - av Ingel, Hans och resten av världen. Mitt i en andhämtning, och mitt i detta Aliides personliga trauma, flyger en sommarfluga rakt in i hennes mun. Det är då och där som fröet gror till hennes senare så förvanskade självbild. Denna skildring av Aliides komplexa relation till systern visar på att den individuella kontexten, såsom starka personliga upplevelser av svek, onekligen kan ligga bakom våldshandlingar som i sig prioriteras framför en gemensam mobilisering mot större politiska orättvisor. ${ }^{13}$

Oksanens heterogena kvinnoskildringar exemplifierar hur svårt det kan vara för kvinnor att förena sig i en gemensam kamp mot strukturellt förtryck. Hennes porträtt står i kontrast till den homogena bild av icke västeuropeiska kvinnor som enligt flera kritiker förekommer i västvärldens beskrivningar. Bland andra har Mohanty ifrågasatt den ofta förenklade definitionen av begreppet Third World Woman som ett monolitiskt subjekt, en definition hon hävdar vittnar om ett kolonialt och hegemoniskt förhållningssätt från västs sida. Följden av ett Third World Woman i singular, blir att det skymmer sikten för alla olikheter som råder mellan och inom olika kulturer. Hon framhåller att eftersom den universella kvinnokampens normbärare har varit västerländska, vita medelklasskvinnor, har konsekvensen blivit att dessa utövat, om än omedvetet, en form av epistemiskt förtryck på alla de ickeeuropeiska kvinnor vars olika kontexter därmed inte har synliggjorts (Mohanty 2003: 17, 48f). ${ }^{14}$ En parallell kan här dras till hur västvärlden enögt ofta har betraktat Östeuropa. I en intervju kritiserar Oksanen den västerländska homogena bilden av Östeuropa och anser att den grundar sig i illusionen om ett enat Europa, tydligast exemplifierat av den Europeiska Unionen. Hon hävdar istället att västeuropéerna omöjligt kan förstå östeuropéernas problem fullt ut, eftersom de inte delar samma traumatiska erfarenheter av sovjetiskt förtryck (Talgre 2012).

Det faktum att Aliide allt eftersom kan identifiera sig med Zara, tyder på att klyftan inom henne håller på att överbryggas i takt med att minnena ges allt tydligare konturer. Aliide återerövrar bilden av sig själv som ett mer självständigt subjekt när hon tillåter sitt $n u$ och då att mötas och skapa större mening. Definitionen av tid och historieskrivning spelar här en viktig roll. Enligt Chakrabarty bör tiden inte tolkas som något homogent, utan istället som ett plural, i form av överskridande "kopplingar” mellan det förflutna och nuet: ”[...] humans from any other period or region - are always in some sense our contemporaries: that would 
have to be the condition under which we can even begin to treat them as intelligible to us. Thus the writing of history must implicitly assume a plurality of times existing together, a disjuncture of the present with itself” (Chakrabarty 2008: 109). En sådan alternativ tidsdefinition innebär att den eurocentriska linjära historieskrivningen ifrågasätts, samtidigt som den finns där för den underordnade rösten att ta spjärn emot, som ett historiskt nav omöjligt att bortse ifrån (Chakrabarty 2008: 5). Mot den bakgrunden kan underordnade människors minnen och kunskaper alltså ges ett slags upprättelse. Relationen mellan minnen och den ickelinjära tiden åskådliggörs även i Oksanens fragmentariska berättarstruktur.

Förutom växlingar mellan tidsplan blandar hon berättarperspektiv och inslag från olika genrer och medier samt spränger in fraser på det lokala språket. Genremässigt kan Utrensning därför beskrivas som en postkolonial roman. ${ }^{15}$ Språkets form överensstämmer med det som Elleke Boehmer menar kännetecknar just det "postkoloniala språket”: Det problematiserar genom att samtidigt verka i motsatta riktningar och syftar till att "resolve as well as make conflict, to go beyond retaliation, to act out, not to foreclose, a dilemma” (Boehmer 2009: 257). I Utrensning överensstämmer den narrativa strukturen och den språkliga gestaltningen med tematiken om människans ambivalens och olösliga livsekvation, en verklighet bestående av fragmentariska och ibland oförenliga element.

På romanens berättarnivå är Zaras estniska språk ett exempel på hur den förflutna tiden, betraktad som en dynamisk del av nuet, kan ha en läkande effekt. Aliide möter först flickans språk med skepsis: ”Trots att [Zara] själv med sitt unga och smutsiga kött hörde till nuet var hennes meningar styva, de kom från en värld av sköra papper och mögliga album som tömts på sina fotografier” (17). På det psykologiska djupet verkar emellertid Zaras språk röra vid onämnbara minnen från Aliides ungdom. ”[D]et fanns en skiftning i flickans estniska, något äldre, gulnat, malätet. På något konstigt sätt kunde man känna lukten av död” (18). Från att ha förknippat Zaras 1940-talsestniska med något statiskt förflutet, blir det så småningom för Aliide något organiskt som "kopplar” tider och rum samman och bär betydelse för hur hon själv kommer att agera. Inte minst sett utifrån ett feministiskt perspektiv kan den alternativa tids- och historiedefinitionen fylla en läkande funktion. Den möjliggör, menar Mohanty, dels att kvinnors underordnade röster ges utrymme att korrigera de luckor och misstolkningar som skapats av den maskulina hegemoniska historieskrivningen, dels att kvinnor med berättandets och skrivandets hjälp kan skapa sig ett självständigt politiskt medvetande (Mohanty 2003: 78f).

\section{Frigörelse}


Kvinnornas avgörande kamp för självständighet återges i en symbolladdad scen i slutet av romanen. När Pasjas svarta Volga plötsligt parkerar på gårdsplanen intill Aliide, har inte Zara något annat val än att fly huset genom ett fönster och hoppas på Aliides lojalitet. Oksanen gestaltar frigörelsen från det sexuella och koloniala förtrycket genom att först låta Zara förstöra de styva fönsterhållarna och sedan genom att låta spindeln slutgiltigt segra över flugan. Passande nog flimrar då även fotot av de forna systrarna förbi som en påminnelse om det som varit och är:

Det fanns ingen tid att fundera. Hon sprang in i den bakre kammaren och bände upp fönsterhållarna av järn. De var styva och svåra att rubba. Hon ryckte i handtaget och fönsterkarmen lossnade. En spindel flydde in under tapeten. Zara öppnade också det yttre fönstret. Spindelväven rämnade och döda flugor trillade ut mellan karmarna. Den annalkande natten slog mot henne och syrsorna knirrade. Mormors fotografi. Hon hade glömt fotografiet. (322)

Med fotografiet förenas historiens då och nu, och vi förstår att Aliide på fotot inte endast tillhör det förflutna utan även är samtida med den Aliide som konverserar med männen på gårdsplanen. Att döma av den överlevande spindeln och de döda flugorna under fönsterkarmen, anar vi var Aliides lojaliteter nu ligger och att den inre kampen är över: hennes destruktiva självbild har övervunnits och hon har återerövrat synen på sig själv som ett självständigt subjekt. När Aliide strax därpå dödar Pasja och Lavri, dödar hon inte bara Zaras utan också sina egna förtryckare, dem som fått henne att förneka sig själv och sina kulturella rötter. Aliides tidigare ickekamp för frihet gör att hon inte fullt ut har kunnat tillgodogöra sig nationens nyvunna frihet utan har fortsatt leva kuvad, och dessutom bespottad av elaka tungor på grund av sitt äktenskap med kommunisten Martin. Det är först med sin våldshandling, när hon riskerar sitt liv i kampen för frihet, som hon återerövrar sin fulla mänskliga frihet. Aliides handling blir, i ljuset av Fanons Hegelinspirerade idéer om våldet som maktspråk, ett nödvändigt ont i det koloniserade jagets kamp för självständighet:

[...] Tillvaron i-sig-för-sig [kan] bara förverkligas genom kamp och den risk det för med sig. Denna risk innebär att jag överskrider i riktning mot det högsta goda, som består i omvandlingen av den subjektiva vissheten som jag har om mitt eget värde till en allmängiltig objektiv sanning. [...] Jag är inte bara häroch-nu, innesluten i tingligheten. Jag finns till för en annan plats och en annan uppgift. (Fanon 2011: 193f)

Aliides insats i kampen är nuet och framtiden, och hon är slutligen beredd att offra sitt liv för sina efterkommande och för erkännandet av den egna kulturen. ${ }^{16}$ Eftersom de förtryckarsystem Aliide och Zara har levt under är helt konstituerade av våld, och 
kompromisser och förhandlingar inte är möjliga, är de tvungna att tillgripa maktens språk för att överhuvudtaget göra sig förstådda. De kan omöjligt formulera sig som självständiga med ett eget språk och på ett trovärdigt sätt, då det språk och de medel som finns att tillgå är skapade av representanter för det koloniala och patriarkala förtrycket. Således tycks det direkta våldet vara det enda möjliga vapnet för Aliide och Zara för att de ska kunna bryta sig fria.

När de två kvinnorna slutligen står enade mot förtryckarmaktens representanter, är det inte endast för att de är kvinnor, utan för att de delar fler erfarenheter än så, i en specifik kontext. Mohanty framhåller att människans verklighet utgörs av ett komplext samspel mellan individers många sociala skikt och att vaga antaganden om "globalt systerskap” därför inte är realistiskt för att kvinnor ska kunna enas i kamp mot ett strukturellt förtryck: "Sisterhood cannot be assumed on the basis of gender; it must be forged in concrete historical and political practice and analysis” (Mohanty 2003: 24). Om man, såsom Mohanty, ser det mänskliga subjektet som skiftande och fragmentariserat, går det inte att separera det diskursivt konstituerade subjektet från den värld hon lever i. Skillnaden mellan subjekt och värld ligger i så fall i tolkarens val av konceptualisering av hennes handlande, den är inte något ontologiskt i sig. I Utrensning går meningen med Aliides handlande (exempelvis dödsskjutningen av hallickarna) följaktligen inte att separera från det sociala sammanhang i vilket handlandet har uppstått (den kontext som leder till att Aliide solidariserar med Zara). Samtidigt kan den enskilda händelsen fördjupa förståelsen av det dubbla förtryckets problematik, ur ett universellt perspektiv. Den intellektuella utmaningen ligger i att se, att när vi specificerar hur det dubbla förtrycket kan ta sig olika uttryck, möjliggör vi ett mer ingående teoretiserande av det universella problemet, då gränserna mellan dimensionerna aldrig är fullständigt slutna. En dylik tolkningsförskjutning av interrelationen mellan det individuella och det universella hjälper oss att bättre förstå hur gränser kan överskridas, exempelvis i form av solidariserandet med den andra (Mohanty 2003: 226).

Solidariteten mellan Aliide och Zara uppnås i en kommunikativ process när ”underdånighetens psykos” har övervunnits och självbilden återerövrats, och när deras olika sociala skikt utmejslas och griper tag i varandras, för att vidgas till något utöver det partikulära, eftersom erfarenheter av förtryck historiskt har delats, och delas, av fler än dem. Med andra ord sammanför Oksanen dimensionerna för det individuella och det universella när hon låter Aliides och Zaras heterogena historier från det perifera Estland representera det dubbla förtrycket som allmängiltigt fenomen. Just denna komplexa interrelation, ”the coimplication of histories with History” (Mohanty 2003: 116), bidrar till att även vi, på 
läsarens nivå, förmår solidarisera med Zaras och Aliides oppositionella handlande. Således skapar romanen betydelseskapande reflektionsrörelser mellan det lokala och det globala, mellan periferier och centrum, men ett centrum vars tolkningsföreträde författaren samtidigt förhåller sig kritisk till. Med Aliides våldsamma motståndshandling markerar Oksanen inte bara två individers frigörelse utan hon markerar även ett kraftfullt ställningstagande mot kolonialt och patriarkalt förtryck i allmänhet, förtryck som äger rum på andra platser, i andra tider, och med andra kontextuella förtecken - men som ekar otäckt igenkännande.

\section{Litteratur}

Bhabha, Homi K. 2004. Of Mimicry and Man. The ambivalence of colonial discourse. I The Location of Culture. London och New York: 121-131.

Boehmer, Elleke 2009. Colonial and Postcolonial Literature. Migrant metaphors. Oxford, New York.

Brah, Avtar 2001. Att inrama Europa på nytt: Genuskonstruerade rasismer, etniciteter och nationalismer i dagens Västeuropa. Postkoloniala texter Catharina Landström (red.). Övers. Ellinor Broman. Stockholm: 173-200.

Chakrabarty, Dipesh 2008. Provincializing Europe. Postcolonial thought and historical difference. Princeton.

Fanon, Frantz 2007. Jordens fördömda. Övers. Per-Olov Zennström. Stockholm.

Fanon, Frantz 2011. Svart hud, vita masker. Övers. Stefan Jordebrandt. Göteborg.

Hamm, Christine 2013. Sofi Oksanen og Estlands fortid: Utrenskning som erindringstekst. Norsk Litteraturvitenskapelig Tidsskrift (1): 17-32.

Kelertas, Violeta 2006a. Baltic Postcolonialism and its Critics. I Violeta Kelertas (red.): Baltic Postcolonialism. On the Boundaries of Two Worlds: Identity, Freedom, and Moral Imagination in the Baltics. Amsterdam, New York: 1-9. 
Kelertas, Violeta 2006b. Perceptions of the Self and the Other in Lithuanian Postcolonial Fiction. I Violeta Kelertas (red.): Baltic Postcolonialism. On the Boundaries of Two Worlds: Identity, Freedom, and Moral Imagination in the Baltics. Amsterdam, New York: 251-269.

Kuokkanen, Rauna m. fl. 2003. Healing the impact of colonization, genocide, and racism on indigenous populations. I Stanley Krippner och Teresa M. McIntyre (red.): The Psychological Impact of War. Trauma on civilians. An international perspective. Westport, Connecticut, London.

Mannheim, Karl 1997. The Problem of Generations. I K. Mannheim (red.): Essays on the Sociology of Knowledge. London: 276-281.

McClintock, Anne 1995. Imperial Leather: Race, Gender and Sexuality in the Colonial Contest. London.

Mohanty, Chandra Talpade 2003. Feminism Without Borders. Decolonizing Theory, Practicing Solidarity. Durham.

Moore, David Chioni 2006. Is the Post-in Postcolonial the Post-in Post-Soviet? Toward a Global Postcolonial Critique. I Violeta Kelertas (red.): Baltic Postcolonialism. On the Boundaries of Two Worlds: Identity, Freedom, and Moral Imagination in the Baltics. Amsterdam, New York: 11-43.

Oksanen, Sofi 2010. Utrensning. Övers. Janina Orlov. Stockholm.

Račevskis, Kārlis 2006. Toward a Postcolonial Perspective on the Baltic States. I Violeta Kelertas (red.): Baltic Postcolonialism. On the Boundaries of Two Worlds: Identity, Freedom, and Moral Imagination in the Baltics. Amsterdam, New York: 165-186.

Sillaste, Kyllike 1995. Conquest and Survival: An Outline of Estonian History. World Affairs (3): 119-123. 
Simonhjell, Nora 2010. '...veggene har ører og i ørene er det vakre øredobber’. Nordisk Råds litteraturpris 2010: Sofi Oksanens Utrenskning. I Norsk litterær årbok 2010: 81-104.

Spivak, Gayatri Chakravorty 1988. Can the subaltern speak? I Cary Nelson och Lawrence Grossberg (red.): Marxism and the Interpretation of Culture. Urbana: 271-313.

Talgre, Marja och Sofi Oksanen 2012. Ett möte med Sofi Oksanen. Kulturradion Biblioteket. 1 juli. Hämtat: 4 april 2013 från http://sverigesradio.se/sida/avsnitt/45142?programid=767

Todorova, Maria 2009. Imagining the Balkans. Oxford.

Tängerstad, Erik 2007. Vi i tredje världen. Fanons försök att grundlägga en global modernitet. Förord till Frantz Fanons Jordens fördömda. Stockholm.

Witt-Brattström, Ebba 2012. Den mörka historien som måste berättas. Om Sofi Oksanens Utrensning. Parnass (2/3): 13-14.

Woolfson, Charles 2007. Labour Standards and Migration in the New Europe. PostCommunist Legacies and Perspectives. European Journal of Industrial Relations 13(2): 199-218.

\section{Noter}

${ }^{1}$ Utrensning har översatts till trettioåtta språk och adaptationer har gjorts till både opera och film. Ursprungligen var Utrensning skriven som ett drama vilket sattes upp 2007 för Nationalteatern i Helsingfors. Oksanens första två romaner är Stalins kossor (2003) och Baby Jane (2005).

${ }^{2}$ Se bl.a. Nora Simonhjell (2010) och Ebba Witt-Brattström (2012).

${ }^{3}$ Det är här viktigt att poängtera att väst/västerlandet som begrepp inte på något sätt är homogent. Det är ändå i sammanhanget användbart som ett analytiskt begrepp i kontrastbelysningen av det ryska och östeuropeiska (som 
förstås inte heller är homogent). Spivak talar om nödvändigheten att ibland tillämpa en sådan form av "strategisk essentialism” (Spivak 1988).

${ }^{4}$ Enligt historikern Erik Tängerstad betecknar Fanons uttryck "Vi i Tredje Världen” alla dem som förespråkar ett alternativ till den kapitalistiska och den kommunistiska världen, de "moderna människor som söker överskrida den västerländska moderniteten för att förverkliga den globala moderniteten” (Tängerstad 2007: 28f). Begreppet "Tredje världen” (Tiers Monde) utvecklades i analogi med "det tredje ståndet” (Tiers État) med ursprung från franska revolutionen. Detta framkommer emellertid inte i översättningen till bl.a. engelskan (Tängerstad 2007: 21).

${ }^{5}$ Många viktiga skillnader förekommer förstås mellan de tre baltiska staterna, beträffande språk, kultur och historia. Ännu en komplicerande faktor i sammanhanget är nationen Rysslands egen kluvna position, belägen i både Europa och Asien.

${ }^{6}$ Estland beviljades medlemskap i EU år 2004.

${ }^{7}$ Se bl.a. Moore (2006: 23) samt Kārlis Račevskis artikel ’Toward a Postcolonial Perspective on the Baltic States” (2006). I den pekar han bl.a. på att definitionen av de forna Sovjetockuperade länderna som "postkoloniala" har komplicerats av att många teoretikers vänsterideologiska övertygelser påverkade deras tolkning av Sovjet som ockupationsmakt.

${ }^{8}$ En parallell kan dras till Fanons resonemang i Svart hud, vita masker om de vitas föreställningar om den svarte mannens kroppslighet och sexuella potens (Fanon 2011: 145ff), dock med den skillnaden att om den andra är man, kan dennes sexualitet upplevas som ett större hot mot kolonialmaktens män.

${ }^{9}$ Angående implikationer av östeuropeisk arbetskraft i Västeuropa, se t.ex. Woolfson (2007). Det är en komplex fråga som utifrån ett annat teoretiskt perspektiv skulle kunna tolkas som inte endast en nackdel för de enskilda. Det är dock en aspekt som ligger utanför ramarna för den här studien.

${ }^{10}$ Jämförelsen mellan Zaras kropp och kaneläpplet är intressant ur flera aspekter. Trädgårdens äpplen och konflikten mellan förtryck och frihetshopp uttrycks nämligen i Paul-Eerik Rummos dikt som inleder romanens andra kapitel: ”I sju miljoner år/ har vi hört führertal/ i sju miljoner år/ sett äppelträden blomma” (105), en dikt som säger något om såväl Aliides som Estlands historia.

11 ”Imperial Leather” bär många betydelselager. Bl.a. kan det välkända tvålmärket symbolisera den västerländska kapitalismens självutnämnda renhet, men kanske anspelar det också på Anne McClintocks spridda bok med samma namn. I den undersöks sambandet mellan brittisk imperialism, kön, ras och klass: Imperial

Leather: Race, Gender and Sexuality in the Colonial Contest (1995).

${ }^{12}$ Berättarstrukturen i Utrensning har även kommenterats av Christine Hamm (2013).

${ }^{13}$ Ur feministisk synvinkel kan Hans Pekk betraktas som det centrum som utgör normen för världen i Aliides ögon. Hon definierar sig själv utifrån detta centrum, the male gaze, och när hon ratas vänder hon aggressiviteten mot den egna, vilken upplevs som en rival.

${ }^{14}$ Fastän Mohanty ser problem med begreppet Third World Woman, understryker hon att detsamma även kan vara användbart som ett strategiskt metodologiskt verktyg. Se ovan, not 3.

${ }^{15}$ I artikeln ”Sofi Oksanen og Estlands fortid: Utrenskning som erindringstekst” argumenterar Christine Hamm för att Utrensning tillhör genren historiografisk metafiktion (efter Linda Hutcheons term). Hon undersöker hur texten uppluckrar gränsen mellan fiktion och historiska faktabeskrivningar, genom sin form av medieöverskridande kollage, samt genom textens gestaltning av minnets omedvetna kroppsliga uttryck (Hamm 
2013). Som jag ser det, motstrider inte Hamms genrebeskrivning och den postkoloniala romangenren varandra, utan de behandlar snarare olika, delvis överlappande, nivåer.

${ }^{16}$ Efter dödskjutningen får läsaren ta del av hur Aliide planerar bereda plats på familjegården åt Zara, Ingel och Linda genom att bränna ner huset och själv möta döden vid sidan av Hans Pekks kvarlevor under lönnkällarens brädgolv (327f). Detta kan liknas vid Spivaks resonemang om den subalterna kvinnans förhållningssätt till den gamla bengaliska änkebränningsritualen sati (Spivak 1988). Likt änkorna vars röster inte kunde göra sig hörda på grund av det dubbla förtrycket i såväl traditionellt kulturella som koloniala maktstrukturer, fattar Aliide det självständiga beslutet att dö, genom en handling som kan tolkas som en stum men talande replik i en större maktdiskurs. 